\title{
PENGARUH STRATEGI PEMBELAJARAN DAN KECERDASAN GANDA TERHADAP HASIL BELAJAR IPS
}

\author{
Maulina Siregar ${ }^{1}$, Abdul Hasan Saragih ${ }^{2}$, R. Mursid ${ }^{3}$ \\ Teknologi Pendidikan, Universitas Negeri Medan \\ Imaulinasiregar@gmail.com, ${ }^{2}$ ahasansaragih@gmail.com, ${ }^{3}$ mursid.tp@gmail.com
}

\begin{abstract}
This study aims to determine the effect of social studies learning outcomes with NHT and STAD learning strategies, to determine the effect of social studies learning outcomes on interpersonal and intrapersonal intelligence, to determine the interaction between learning strategies and multiple intelligences on social studies learning outcomes. The research population of the XI grade students of SMK Negeri 1 Meranti. The research sample of class XI students consisted of 2 classes. The sampling technique was cluster random sampling. The research method used a quasi-experimental design with a factor of $2 \times 2$. The data analysis technique used was two-way ANOVA with a significance level of $\alpha=0.05$. The results showed that: The social studies learning achievement of students who were taught with the NHT learning strategy was higher than students who were taught with the STAD Learning Strategy; The learning achievement of students who had interpersonal intelligence was higher than students who had intrapersonal intelligence; and there is an interaction between NHT learning strategies and STAD learning strategies and multiple intelligences (intrapersonal and interpersonal intelligence) on students' social studies learning achievement. Based on the average score of students, it indicates that groups of students who have interpersonal intelligence will be better taught using the NHT learning strategy and students who have intrapersonal intelligence will be better taught using the STAD learning strategy.
\end{abstract}

Keywords: learning strategy, multiple intelligence, social science

Abstrak: Penelitian bertujuan untuk mengetahui pengaruh hasil belajar IPS dengan startegi pembelajaran NHT dan STAD, mengetahui pengaruh hasil belajar IPS terhadap kecerdasan interpersonal dan intrapersonal, mengetahui adanya interaksi antara strategi pembelajaran dan kecerdasan ganda terhadap hasil belajar IPS. Populasi penelitian siswa kelas XI SMK Negeri 1 Meranti. Sampel penelitian siswa kelas XI yang terdiri dari 2 kelas. Teknik pengambilan sampel adalah cluster random sampling. Metode penelitian menggunakan desain eksperimen semu dengan faktor $2 \times 2$. Teknik analisis data yang digunakan adalah ANOVA dua jalur dengan taraf signifikansi $\alpha=0,05$. Hasil penelitian menunjukkan bahwa: Prestasi belajar IPS siswa yang diajar dengan strategi pembelajaran NHT lebih tinggi daripada siswa yang diajar dengan Strategi Pembelajaran STAD;Prestasi belajar siswa yang memiliki kecerdasan interpersonal lebih tinggi daripada siswa yang memiliki kecerdasan intrapersonal; dan terdapat interaksi antara strategi pembelajaran NHT dan strategi pembelajaran STAD dan kecerdasan berganda (kecerdasan intrapersonal dan interpersonal) terhadap prestasi belajar IPS siswa. Berdasarkan nilai rata-rata siswa memberikan indikasi bahwa kelompok siswa yang memiliki kecerdasan interpersonal akan lebih baik diajar dengan menggunakan strategi pembelajaran NHT dan siswa yang memiliki kecerdasan intrapersonal akan lebih baik diajar dengan menggunakan strategi pembelajaran STAD.

Kata Kunci: strategi pembelajaran, kecerdasan ganda, ilmu pengetahuan sosial

\section{PENDAHULUAN}

Pada hakikatnya belajar adalah proses perubahan tingkah laku individu yang penekanannya ditujukan pada siswa. Menurut konstruktivistik belajar juga diartikan sebagai suatu proses pembentukan pengetahuan dimana siswa diharapkan mampu membangun atau merekonstruksi pengetahuannya melalui aktivitas pembelajaran yang dilakukan. Namun demikian pada prosesnya belajar juga memiliki kaitan yang sangat signifikan dengan pendidikan, dimana untuk mengukur kualitas suatu sistem pendidikan dapat terlihat dari proses pembelajaran yang efektif dengan menggunakan sumber daya yang memadai sehingga siswa memiliki kompetensi yang dikehendaki dari tujuan pembelajaran.

Sebagai pengelola (manager) guru harus memiliki kompetensi memanfaatkan sumber daya yang ada secara efektif dan efisien dan sebagai evaluator guru harus memiliki kompetensi dalam membuat tes evaluasi yang merupakan pencerminan suksesnya seorang guru dalam mencapai tujuan pembelajaran, yang pada akhirnya bertujuan untuk memudahkan siswa dalam mengatasi masalah- 
masalah pada proses pembelajaran sehingga tujuan pembelajaran dapat tercapai sesuai harapan.

Berbagai strategi pembelajaran telah ditawarkan oleh para ahli guna mengatasi masalah-masalah pembelajaran. Di antaranya strategi pembelajaran adalah Numbered Head Together (NHT) dan Student Teams Achievement Division (STAD). NHT atau penomoran berpikir bersama merupakan tipe dari pembelajaran kooperatif yang dirancang untuk mempengaruhi pola interaksi siswa dan sebagai alternatif terhadap struktur kelas tradisional. Sedangkan STAD adalah model pembelajaran kooperatif dengan menggunakan kelompok-kelompok kecil dengan jumlah anggota tiap kelompok 4-5 orang siswa secara heterogen. Di awali dengan penyampaian tujuan pembelajaran, penyampaian materi, kegiatan kelompok, kuis dan penghargaan kelompok. Kedua strategi pembelajaran tersebut merupakan tipe dari model pembelajaran kooperatif di mana guru hanya berperan sebagai fasilitator dan motivator dalam proses pembelajaran sehingga siswa mampu mencapai tujuan dari kompetensi yang diharapkan.

Strategi pembelajaran bukanlah satusatunya faktor yang paling menentukan keberhasilan suatu pencapaian tujuan pembelajaran, tetapi ini semua merupakan suatu kompleksitas yang memerlukan pengkajian yang lebih mendalam. Hal ini juga terkait dengan kecerdasan yang dimiliki siswa itu sendiri, yang sering kita sebut dengan kecerdasan ganda (Multiple intelegences). Terdapat delapan kecerdasan ganda di antaranya adalah kecerdasan intrapersonal dan kecerdasan interpersonal. Menurut Wijanarko (2010) kecerdasan intrapersonal adalah kemampuan seseorang berkomunikasi dan memandang diri sendiri (Self Image) serta kemampuan seseorang mengendalikan dirinya (Self Control). Sedangkan kecerdasan interpersonal adalah kemampuan seseorang untuk berkomunikasi dengan orang lain atau kemampuan bersosialisasi dengan menunjukkan sikap empati dan simpati. Dengan demikian antara strategi pembelajaran dengan karakteristik peserta didik memiliki hubungan yang sangat signifikan dalam proses pembelajaran, dimana proses tersebut dinyatakan berhasil apabila siswa mampu menguasai kompetensi dari materi ajar.

Fakta di lapangan menunjukan adanya masalah pada proses pembelajaran termasuk pembelajaran IPS, sehingga menimbulkan gap/kesenjangan antara apa yang diharapkan dengan kenyaataan. Dalam hal ini, kesalahan mungkin bukan terjadi pada siswa yang kurang memperhatikan materi ajar tetapi justru kompetensi guru dalam memilih strategi pembelajaran yang harus disesuaikan dengan karekteristik siswa itu sendiri.

Begitu kompleknya permasalahan dalam dunia pendidikan, sehingga tuntutan kepada guru untuk lebih keratif dan inovatif dalam melakukan pemilihan strategi pembelajaran semakin gencar dilakukan. Namun demikian pemilihan strategi pembelajaran yang sesuai dan tepat bukan jaminan utama keberhasilan proses pembelajaran. Karenanya penelitian ini mencoba mencari solusi dengan menggunakan strategi pembelajaran NHT dan STAD untuk mengajarkan materi Keberagaman Budaya di Indonesia pada mata pelajaran IPS kelas XI semester genap di SMK Negeri I Meranti. Dasar pemilihan materi ini karena penulis beranggapan bahwa kehidupan modern sekarang ini menuntut setiap individu untuk lebih mampu melakukan kontrol dan filterisasi terhadap pengaruh dari diri sendiri maupun orang lain serta menghargai perbedaan demi terciptanya sebuah kondisi masyarakat yang lebih harmonis yang sesuai dengan cita-cita Pancasila.

\section{Hakikat Belajar IPS}

Istilah belajar sudah tidak asing lagi terdengar di telinga terlebih lagi dalam dunia pendidikan. Belajar didefinisikan sebagai suatu proses perubahan tingkahlaku yang didapat dari pengalaman-pengalaman dan lebih bersifat permanen. Lebih lanjut Chaplin (1972) dalam Dictionary of Psychology menyatakan ada dua definisi belajar. Peryataan pertama berbunyi: "Belajar adalah perolehan perubahan tingkahlaku yang relatif menetap sebagai akibat latihan dan pengalaman". Pernyataan kedua berbunyi: "Belajar adalah proses memperoleh respon-respon sebagai akibat adanya latihan khusus". Sedangkan Bruner (dalam Hamid, 2009) menyatakan bahwa belajar adalah 1) perolehan pengetahuan adalah suatu proses interaktif maksudnya ketika seseorang berinteraksi dengan lingkungannya secara otomatis terjadi perubahan pada diri maupun lingkungannya tersebut. 2) mengkonstruksi pengetahuannya dengan jalan menghubungkan 
informasi yang baru diterima dengan informasi yang dimiliki.

Menurut konstruktivisme (dalam

Hamid, 2009) belajar adalah proses mengasimilasi dan menghubungkan pengalaman atau informasi yang dipelajari dengan pengertian yang sudah dimiliki seseorang sehingga pengetahuannya berkembang. Gagne (dalam Djamarah dan Zain, 2010) mengulas tentang definisi belajar dengan menyatakan delapan tipe pola-pola pembelajaran yaitu: 1) signal learning (belajar isyarat) dengan kata lain belajar pada tipe ini lebih bersifat involuntary (tidak sengaja dan tidak disadari tujuannya). 2) Stimulus-respon learning (belajar stimulus-respon). Tipe ini termasuk kedalam instrumental condition atau trial and error (mencoba-coba). 3) Chaining (Rantai atau rangkaian). Dengan kata lain siswa berusaha merangkaikan antara stimulus dan respon yang satu dengan yang lain. Mengarah kepada hubungan berantai. 4) Verbal Association (Assosiasi verbal). Belajar tipe ini memilki kecendrungan mencari persamaan. 5) Diskrimination Learning (Belajar diskriminasi). Pada tipe ini diharapkan siswa mampu mengadakan pembeda atau melakukan seleksi dan pengujian di antara dua perangsang atau sejumlah stimulus yang diterimanya. 6) Concept Learning (Belajar konsep) atau belajar pengertian. 7) Rule learning (belajar aturan). Pada tipe ini siswa mulai belajar membuat generalisasi, hukum dan kaidah. 8) Problem solving (Pemecahan masalah). Belajar pada tipe terakhir ini di mana siswa dituntut untuk mengatasi-mengatasi masalah-masalah yang timbul dalam kehidupan sehari-harinya.

Kurikulum IPS sebagaimana yang dinyatakan Hasan (1996) bahwa IPS merupakan fusi dari berbagai disiplin ilmu. IPS juga membahas hubungan antara manusia dengan lingkungannya. Lingkungan masyarakat di mana siswa tumbuh dan berkembang dari masyarakat, dihadapkan dari berbagai permasalahan yang ada dan terjadi di lingkungan sekitarnya. IPS berusaha membantu siswa dalam memecahkan permasalahan yang dihadapi sehingga akan menjadikannya semakin mengerti dan memahami lingkungan sosial masyarakatnya (Kosasih dalam Solihatin dan Raharjo, 2009). Gross (dalam Solihatin dan Raharjo, 2009) menyebutkan bahwa tujuan pembelajaran IPS adalah mempersiapkan siswa menjadi warga negara yang baik dalam kehidupannya di masyarakat dan untuk mengembangkan kemampuan siswa menggunakan penalaran dalam mengambil keputusan setiap persoalan yang dihadapinya.

Menurut Solihatin dan Raharjo (2009), terdapat empat belas konsep pembelajaran IPS di Indonesia yaitu: 1) Interaksi; hubungan timbal-balik antar individu, individu dengan kelompok serta kelompok dengan kelompok sehingga terbentuk suatu kerjasama. 2) Saling ketergantungan; sebagai makhluk sosial manusia tidak dapat hidup tanpa bantuan orang lain. 3) Kesinambungan dan perubahan (Continuity and change); kesinambungan dapat terjadi pada suatu masyarakat karena adanya lembaga perkawinan, dari sinilah sejumlah nilai, simbol dan kebiasaan-kebiasaan diwariskan dari generasi ke generasi. Sedangkan perubahan sosial dapat terjadi karena berbagai sebab antara lain politik, ekonomi dan teknologi. 4) Keragaman/kesamaan/perbedaan. 5) Konflik dan konsensus. 6) Pola (Pattern); suatu corak, model, atau bentuk yang sama, yang ditiru, yang terulang, dan bersifat repetitif. Setiap pribadi maupun masyarakat memiliki pola hidup tersendiri. 7) Tempat (Lokasi); setiap makhluk hidup pasti akan menempati ruang dan waktu. 8) Kekuasaan (power); kemampuan membuat orang lain melakukan sesuatu sesuai dengan yang dikehendaki. 9) Nilai kepercayaan; nilai merupakan keyakinan yang dipegang dan dilaksanakan dari generasi ke generasi secara turun temurun dipelihara. 10) Keadilan dan pemerataan; keadilan akan lebih mudah dirasakan dengan jalan melakukan pemerataan. 11) Kelangkaan (Scarcity); fenomena kelangkaan atau keterbatasan harus menjadi perhatian semua pihak pada era globalisasi sekarang ini. 12) Kekhususan (Specialization) 13) Budaya (Culture) 14) Nasionalisme; rasa cinta terhadap tanah air dan bangsa.

\section{Hakikat Strategi Pembelajaran}

Strategi dalam pembelajaran adalah cara atau upaya seorang guru mencapai target utama di dalam proses pembelajaran, di mana target utama dalam proses tersebut adalah tercapainya kompetensi pembelajaran oleh siswa. Dick \& Carey (2005) mendefinisikan strategi pembelajaran sebagai suatu pendekatan dalam mengolah secara sistematis pembelajaran sehingga siswa dapat menguasai isi pembelajaran atau mencapai tujuan yang diharapkan. Selanjutnya Miarso (2009) menyebutkan bahwa strategi pembelajaran 
adalah pendekatan menyeluruh pembelajaran dalam suatu sistem pembelajaran, yang berupa pedoman umum dan kerangka kegiatan untuk mencapai tujuan umum pembelajaran.

Sudrajat (dalam Sanjaya, 2010), menerangkan bahwa terdapat empat unsur strategi pembelajaran yaitu: 1) Menetapkan spesifikasi dan kualifikasi tujuan pembelajaran yakni perubahan profil perilaku dan pribadi siswa. 2) Mempertimbangkan dan memilih sistem pendekatan pembelajaran yang dipandang paling efektif. 3) Mempertimbangkan dan menetapkan langkahlangkah atau prosedur, metode dan teknik pembelajaran. 4) Menetapkan norma-norma dan batas minimum ukuran keberhasilan atau kriteria dan ukuran baku keberhasilan.

Mengutip pendapat Kemp (dalam Sanjaya, 2010) menjelaskan bahwa strategi pembelajaran adalah suatu kegiatan pembelajaran yang harus dikerjakan guru dan siswa agar tujuan pembelajaran dapat dicapai secara efektif dan efisien. Lebih lanjut Regeluth (dalam Sanjaya, 2010) menyatakan bahwa strategi dibedakan menjadi dua yaitu strategi makro dan strategi mikro. Strategi makro adalah strategi yang menata keseluruhan isi pembelajaran yang terdiri dari satu ide (prinsip, konsep atau prosedur), sedangkan strategi mikro adalah strategi untuk menata urutan sajian untuk satu ide tunggal (konsep, prinsip maupun prosedur).

Terdapat berbagai tipe model pembelajaran yang dikemukan para ahli, salah satunya adalah model pembelajaran kooperatif yang tujuan utamanya memaksimalkan aktivitas siswa dalam proses pembelajaran. Isjoni (2009) menyatakan bahwa pembelajaran kooperatif adalah salah satu bentuk pembelajaran yang berdasarkan faham konstruktivis. Hal senada juga diungkapkan Lungdren (dalam Isjoni, 2009) bahwa terdapat tujuh unsur dasar pembelajaran kooperatif yaitu: 1) para siswa memiliki persepsi bahwa mereka "tenggelam atau berenang bersema" 2) para siswa harus memiliki tanggungjawab terhadap anggota kelompoknya dalam mempelajari materi yang dihadapi 3) para siswa harus berpandangan bahwa mereka semua memiliki tujuan yang sama 4) para siswa membagi tugas dan berbagi tanggung jawab diantara para anggota kelompok 5) para siswa diberikan satu evaluasi atau penghargaan yang akan ikut berpengaruh terhadap evaluasi kelompok 6) para siswa berbagi kepemimpinan sementara mereka memperoleh keterampilan bekerjasama selama belajar 7) setiap siswa akan diminta mempertanggungjawabkan secara individual materi yang ditangani dalam kelompok kooperatif.

Di dalam model pembelajaran kooperatif tersebut terdapat delapan strategi pembelajaran yaitu STAD, Kelompok Ahli (Jigsaw), Investigasi Kelompok (Kelompok Investigasi), TPS, NHT, TGT, Rotation Trio Exchange (RTE) dan Group Resume (GR). Namun dalam penelitian ini yang diuji pengaruhnya terhadap hasil belajar IPS hanya strategi pembelajaran NHT dan STAD.

\section{Strategi Pembelajaran Numbered Head Together (NHT)}

Strategi pembelajaran ini pada hakikatnya adalah pengembangan dari diskusi kelompok yang memiliki ciri khas penghunjukkan seorang siswa yang mewakili kelompoknya tanpa memberitahukan terlebih dahulu. Lebih lanjut Lie (2002) menyatakan bahwa prosedur teknik numbered head together adalah saat pemanggilan siswa untuk menjawab atau melakukan sesuatu yang dipanggil adalah nomor kepala dari salah satu kelompok secara acak. Hal ini akan membuat semua siswa harus siap dan penghargaan akan diberikan jika jawaban benar untuk nilai kelompok. Teknik ini memberikan kesempatan kepada semua siswa dalam kelompok untuk saling memberikan ide dan mempertimbangkan jawaban yang paling tepat, mendorong siswa untuk meningkatkan semangat kerjasama mereka.

Lebih lanjut Ibrahim, dkk (2000) mengemukakan tiga tujuan yang hendak dicapai dalam pembelajaran kooperatif dengan tipe NHT yaitu : 1) Hasil belajar akademik stuktural; bertujuan untuk meningkatkan kinerja siswa dalam tugas-tugas akademik. 2) Pengakuan adanya keragaman; bertujuan agar siswa dapat menerima teman-temannya yang mempunyai berbagai latar belakang. 3) Pengembangan keterampilan sosial; bertujuan untuk mengembangkan keterampilan sosial siswa. Keterampilan yang di maksud antara lain berbagi tugas, aktif bertanya, menghargai pendapat orang lain, mau menjelaskan ide atau pendapat, bekerja dalam kelompok dan sebagainya.

\section{Strategi Pembelajaran Student Teams Achievement Division (STAD)}


Pembelajaran kooperatif tipe STAD merupakan salah satu strategi pembelajaran yang dikembangkan oleh Robert E. Slavin yang menekankan adanya aktivitas dan interaksi di antara siswa untuk saling memotivasi dan saling membantu dalam menguasai materi pelajaran guna mencapai prestasi yang maksimal. Fokus dari strategi ini adalah keberhasilan pencapaian kompetensi oleh kelompok dengan asumsi bahwa kompetensi hanya dapat dicapai jika setiap anggota kelompok berusaha menguasai materi ajar yang menjadi pembahasan.

$$
\text { Lebih lanjut Slavin }
$$

mengemukakan bahwa strategi pembelajaran STAD terdiri atas lima komponen utama yaitu: 1) Presentasi Kelas; 2) Kerja Kelompok; 3) dan Pemberian Kuis. Slavin (2008) mengatakan ada beberapa masalah dalam menerapkan strategi belajar bersama di kelas yaitu ramai, gagal untuk saling mengenal, perilaku yang salah dan penggunaan waktu yang kurang efektif.

\section{Hakikat Kecerdasan Ganda (Multiple Intellegences)}

Kecerdasan (Intelligence) memiliki pengertian yang sangat luas. Para ahli psikologi mengartikan kecerdasan sebagai keseluruhan kemampuan individu untuk memperoleh pengetahuan, menguasainya dan mempraktekkannya dalam pemecahan suatu masalah. Menurut Safaria (2005), kecerdasan merupakan kemampuan yang dimiliki seseorang untuk melihat suatu masalah lalu menyelesaikannya atau membuat sesuatu yang dapat berguna bagi orang lain. Menurut Budiningsih (2008) kecerdasan adalah suatu kemampuan untuk memecahkan masalah atau menghasilkan sesuatu yang dibutuhkan di dalam latar budaya tertentu.

Pembahasan tentang kecerdasan telah banyak dikemukakan oleh pakar seperti yang telah dijelaskan di atas. Sedang Armstrong menambahkan satu teori lagi yang banyak dikaji, yaitu dari Guillford dengan teori Structure Intelligence. Menurut Amstrong (2004), kecerdasan adalah kemampuan untuk menangkap situasi baru serta kemampuan untuk belajar dari pengalaman masa lalu seseorang. Pada perkembangan selanjutnya para pakar kecerdasan, antara lain Goleman dengan teori Emotional Intelligence dan Gardner dengan teori Multiple Intelligence (Gunawan, 2003) secara singkat mengemukakan defenisi kecerdasan yang dinyatakan sebagai potensi atau kemampuan seseorang yang perlu dikembangkan. Seiring dengan perkembangan teori kecerdasaan tersebut, telah terjadi pergeseran dari kecerdasan sebagai kemampuan umum beralih kepada kecerdasan sebagai kemampuan khusus yang memiliki beberapa bagian atau bahkan banyak domain. Peralihan tersebut menurut Semiawan (2004), kelihatan dalam pengembangan individu yang mengacu kepada pendapat yang menunjukkan bahwa perkembangan manusia diwujudkan melalui ragam aspek yang berbeda. Hal tersebut merupakan pertanda bahwa teori kecerdasan ganda (multiple intelligence) mulai mendapat perhatian untuk digunakan sebagai acuan dalam berbagai aktivitas untuk memacu perkembangan manusia termasuk aktivitas pembelajaran di sekolah-sekolah.

Teori kecerdasan ganda pertama kali dikemukakan oleh Howard Gardner dalam bukunya Frames of Mind pada tahun 1983. Gardner (1983), mengembangkan teori kecerdasan ganda berdasarkan kriteria yang terdiri dari delapan faktor, yaitu 1) adanya pembagian wilayah kecerdasan pada struktur otak, seperti central core, sistem limbik dan hemisfer serebral, 2) terdapat kecerdasan yang menonjol pada orang tertentu (savant dan genius), 3) kecerdasan berkaitan dengan kebudayaan dan berkembang mengikuti pola perkembangan tertentu, 4) memiliki konteks historis, 5) memiliki hubungan dengan temuan psikometrik, 6) memiliki hubungan dengan hasil penelitian psikologi eksperimental, 7) cara kerja atau rangkaian cara kerja dasar dapat diidentifikasi, dan 8) memiliki sistem penandaan atau symbol khas sendiri. Kriteria yang dikemukakan Gardner tersebut sebagai bukti bahwa teori kecerdasan ganda tidak hanya dikembangkan berdasarkan hasil kajiannya sendiri, tetapi juga menggunakan dasar dan hasil kerja para pakar teori perkembangan dan kecerdasan yang muncul lebih dahulu.

Gardner (1993), mengemukakan bahwa kecerdasan adalah kemampuan yang berkaitan dengan tiga hal, yaitu kemampuan untuk: 1) memecahkan masalah yang terjadi dalam kehidupan sehari-hari, 2) menghasilkan persoalan-persoalan baru untuk diselesaikan, dan 3) menciptakan sesuatu atau menawarkan jasa yang akan memberikan penghargaan dalam budaya setempat. Berdasarkan penjelasan yang dikemukakan Gardner tersebut dapat dinyatakan bahwa kecerdasan sebagai suatu kemampuan yang dimiliki individu yang dapat berkembang secara alami dan dapat pula 
dikembangkan melalui pembelajaran dan pengalaman. Ini berarti lingkungan dapat berperan dalam membantu individu untuk mengembangkan kemampuannya.

Samples (2002), mengemukakan bahwa kecerdasan merupakan kemampuan melakukan sesuatu yang bermanfaat dalam masyarakat di lingkungan sekitar. Sedang Gottfredson yang dikutip Elliott, $d k k$ (2000), mengemukakan bahwa kecerdasan merupakan kemampuan mental yang bersifat umum, yang diantaranya sebagai kemampuan untuk menelaah (to reason), merencanakan, memecahkan masalah, berpikir abstrak, mengemukakan ide-ide, belajar cepat dan belajar dari pengalaman. Kedua pendapat tersebut menegaskan bahwa kecerdasan sebagai suatu kemampuan yang berfungsi untuk menelaah, merencanakan, memecahkan masalah, berpikir abstrak, mengemukakan ide-ide yang diperoleh dari belajar dan pada akhirnya berguna bagi kehidupan manusia.

Pendapat lain tentang kecerdasan dikemukakan oleh Lazear (2000), yang menyatakan bahwa seseorang yang cerdas adalah: 1) mereka yang dapat memecahkan permasalahan yang mereka hadapi dalam hidupnya, 2) mereka yang dapat menghadapi berbagai tantangan hidup dengan kreatif, dan 3) mereka yang dapat menghasilkan berbagai hal bermanfaat bagi dirinya dan orang lain. Pendapat ini menunjukkan bahwa kecerdasan berkaitan dengan kemampuan untuk memecahkan masalah, menghadapi tantangan, dan menghasilkan sesuatu yang bermanfaat. Lebih lanjut Gardner (1993), berkeyakinan bahwa semua manusia memiliki lebih dari satu kecerdasan (inteligensi) melainkan group abilities.

\section{Kecerdasan Intrapersonal}

Kecerdasan intrapersonal menurut Gardner (1993), merupakan kemampuan memahami hal-hal yang berkaitan dengan perasaan-perasaan yang ada pada diri sendiri, seperti perasaan senang ataupun sedih, apa yang dapat ia lakukan, apa yang ingin ia lakukan, bagaimana ia bereaksi terhadap hal-hal tertentu, hal-hal yang mana yang perlu dihindari, dan hal-hal yang mana yang didekati. Sedang Lazear (2000), menyatakan bahwa kecerdasan intrapersonal merupakan kemampuan introspeksi diri yang membuka peluang untuk merefleksi diri sehingga menyadari semua aspek dalam diri, seperti pengetahuan tentang perasaan sendiri, proses berpikir, refleksi diri dan rasa tentang hasrat yang dimiliki yang bertumpu pada dua hal, yaitu identitas diri dan kemampuan (ability) untuk mengenal kekuatan dan kelemahan diri sendiri. Lebih lanjut menurut Amstrong, kecerdasan intrapersonal secara luas diartikan sebagai kecerdasan yang dimiliki individu untuk mampu memahami dirinya. Sedangkan, dalam arti sempit ialah kemampuan seseorang mengenal dan mengindentifikasi emosi, juga keinginannya. Selain itu seseorang juga mampu memikirkan tindakan yang sebaiknya dilakukan dan memotivasi dirinya sendiri. Seseorang dengan karakter ini mampu mengintropeksi dirinya dan memperbaiki kekurangannya. Setiap orang dianugerahi kecerdasan ini, namun kadarnya berbeda-beda (Amstrong, 2004).

Lebih lanjut Sujiono dan Sujiono (2010) mengemukakan bahwa terdapat beberapa cara untuk mengembangkan kecerdasan intrapersonal yaitu: 1) menciptakan citra diri yang positif, "aku anak baik". 2) menampilkan sikap hangat tapi tegas sehingga anak tetap dapat memiliki sikap hormat. 3) ciptakan suasana serta situasi yang kondusif. Dengan kata lain kecerdasan intrapersonal adalah kemampuan untuk mengenali diri sendiri dengan memiliki konsep serta citra diri yang positif atau alat untuk memberikan kontrol dan intropeksi diri dalam menjalani kehidupan sehingga terbentuklah kepribadian yang tidak terombang ambing oleh pengaruh-pengaruh eksternal.

\section{Kecerdasan Interpersonal}

Kecerdasan interpersonal

(interpersonal intellegence) adalah salah satu dari delapan kecerdasan ganda yag dikemukakan oleh Gardner (1983), dalam bukunya "Frames Of Mind: The Theory of Multiple Intelligences". Kecerdasan interpersonal adalah kemampuan untuk mengamati dan mengerti maksud, motivasi dan perasaan orang lain. Peka pada ekspresi wajah, suara dan gerakan tubuh orang lain dan ia mampu memberikan respon secara efektif dalam berkomunikasi. Lebih lanjut Gardner (2000), mengemukakan bahwa kecerdasan interpersonal merupakan kemampuan melihat dan memahami perbedaan mood, temperamen, motivasi dan hasrat orang lain yang memiliki keinginan untuk bekerja sama dengan mereka. Hal senada diungkapkan Lazear (2000), menjelaskan bahwa kecerdasan interpersonal 
merupakan kemampuan (ability) yang digunakan untuk berkomunikasi secara verbal dan non verbal serta kemampuan yang digunakan untuk melihat perbedaan mood, temperamen, motivasi dan hasrat orang lain dengan diri sendiri. Pendapat lain dikemukakan oleh Amstrong (2004), menyatakan bahwa kecerdasan interpersonal merupakan kemampuan mempersepsi dan membedakan suasana hati, maksud, motivasi serta perasaan orang lain. Dari ketiga pendapat tersebut dapat dinyatakan bahwa kecerdasan interpersonal sebagai kemampuan melihat orang lain yang meliputi kepekaan pada ekspresi wajah, suara, gerak-isyarat orang lain dan dapat berinteraksi dengan orang lain.

Salah seorang psikolog dari Inggris, NK Humphrey dikutip dari Amstrong (2003), mengatakan kecerdasan interpersonal yang merupakan bagian dari kemampuan sosial ini, merupakan hal penting dari kecerdasan manusia karena manfaat terbesar dari pikiran manusia adalah untuk mempertahankan kehidupan sosial dengan cara yang efektif. Lebih lanjut menurut Anderson (dalam Safaria, 2005), kecerdasan interpersonal mempunyai tiga dimensi, yaitu: Social sensitivity, Social insight, dan Social communication.

Ketiga dimensi tersebut merupakan satu kesatuan yang utuh dan ketiganya saling mengisi satu sama lainnya. a. Social sensitivity; Kemampuan individu untuk bisa merasakan dan mengamati reaksi-reaksi atau perubahan individu lain yang ditunjukkan baik secara verbal maupun non verbal. Seseorang yang memiliki sensitivitas yang tinggi akan mudah memahami dan menyadari adanya reaksi-reaksi tertentu dari orang lain, entah reaksi tersebut positif ataupun negatif.

b. Social insight; Kemampuan seseorang untuk memahami dan mencari pemecahan masalah yang efektif dalam satu interaksi sosial, sehingga masalah-masalah tersebut tidak menghambat apalagi menghancurkan relasi sosial yang telah dibangun. Pondasi dasar dari social insight ini adalah berkembangnya kesadaran diri secara baik, kesadaran diri yang berkembang akan membuat seseorang mampu memahami keadaan dirinya baik keadaan internal maupun eksternal.

c. Social communication; penguasaan keterampilan komunikasi sosial merupakan kemampuan individu untuk menggunakan proses komunikasi dalam menjalin dan membangun hubungan interpersonal yang sehat. Keterampilan komunikasi yang harus dikuasai adalah keterampilan mendengarkan afektif, berbicara afektif, keterampilan public speaking dan keterampilan menulis secara efektif.

Tabel 1. Perbedaan Karakteristik Antara Kecerdasan Interpersonal dan Kecerdasan Intrapersonal

\begin{tabular}{|c|c|c|}
\hline No & Kecerdasan Interpersonal & Kecerdasan Intrapersonal \\
\hline 1. & $\begin{array}{l}\text { Terikat dengan orang tua dan berinteraksi } \\
\text { dengan orang lain }\end{array}$ & Sadar akan wilayah emosinya \\
\hline 2. & Membentuk dan menjaga hubungan sosial & $\begin{array}{l}\text { Menemukan cara-cara dan jalan } \\
\text { keluar untuk mengekspresikan } \\
\text { perasaan dan pemikirannya }\end{array}$ \\
\hline 3. & $\begin{array}{l}\text { Mengetahui dan menggunakan cara-cara yang } \\
\text { beragam dalam berhubungan dengan orang lain. }\end{array}$ & $\begin{array}{l}\text { Mengembangkan model diri yang } \\
\text { akurat }\end{array}$ \\
\hline 4. & $\begin{array}{l}\text { Merasakan perasaan, pikiran, motivasi, tingkah } \\
\text { laku dan gaya hidup orang lain }\end{array}$ & $\begin{array}{l}\text { Termotivasi untuk mengidentifikasi } \\
\text { dan memperjuangkan tujuannya }\end{array}$ \\
\hline 5. & $\begin{array}{l}\text { Berpartisipasi dalam kegiatan kolaboratif dan } \\
\text { menerima bermacam peran yang perlu } \\
\text { dilaksanakan oleh bawahan sampai pimpinan, } \\
\text { dalam suatu usaha bersama }\end{array}$ & $\begin{array}{l}\text { Membangun dan hidup dengan suatu } \\
\text { sistem nilai etik (agama) }\end{array}$ \\
\hline 6. & npengaruhi pendapat dan perbuatan orang & Bekerja mandiri \\
\hline 7. & $\begin{array}{l}\text { Memahami dan berkomunikasi secara efektif, } \\
\text { baik dengan cara verbal maupun non verbal }\end{array}$ & $\begin{array}{l}\text { Penasaran akan "pertanyaan besar" } \\
\text { tentang makna kehidupan, relevansi, } \\
\text { dan tujuannya }\end{array}$ \\
\hline 8. & $\begin{array}{l}\text { Menyesuaikan diri terhadap lingkungan dan grup } \\
\text { yang berbeda dan juga umpan balik (feedback) } \\
\text { dari orang lain }\end{array}$ & $\begin{array}{l}\text { Mengatur secara r kontiniu } \\
\text { pembelajaran dan perkembangan } \\
\text { tujuan personalnya }\end{array}$ \\
\hline
\end{tabular}


9. Menerima perspektif yang bermacam-macam dalam masalah sosial dan politik

10. Mempelajari keterampilan yang berhubungan dengan penengah sengketa (moderator)

11. Tertarik pada karir yang berorientasi interpersonal seperti mengajar, pekerjaan sosial, konseling, manajemen atau politik

12. Membentuk proses sosial atau model yang baru Memberdayakan orang lain
Berusaha mencari dan memahami pengalaman "batinnya" sendiri

Mendapatkan wawasan dalam kompleksitas diri dan eksistensi manusia

Berusaha untuk mengaktualisasikan diri

\section{METODOLOGI PENELITIAN}

Penelitian ini dilaksanakan di SMK Negeri I Meranti Kabupaten Asahan. Pada materi Keragaman budaya di Indonesia. Populasi penelitian adalah seluruh siswa kelas XI SMK Negeri 1 Meranti yang berjumlah 5 kelas sebanyak 170 siswa. Sampel penelitian adalah siswa kelas XI sebanyak 2 kelas. Teknik pengambilan sampel dilakukan dengan cluster random sampling. Penelitian ini menggunakan metode kuasi-eksperimen dengan desain penelitian faktorial $2 \times 2$. Instrumen yang digunakan adalah tes hasil belajar IPS sebanyak 32 soal dalam bentuk pilihan berganda dengan
4 pilihan yang telah dinyatakan valid dan angket kecerdasan ganda sebanyak 35 butir dengan 2 pilihan jawaban (pilihan a dan b). Teknik analisis data yang digunakan adalah ANAVA dua jalur pada taraf signifikan $\alpha=$ 0,05 .

\section{HASIL}

Data-data hasil temuan penelitian dikelompok berdasarkan interaksi antara strategi pembelajaran dengan kecerdasan ganda siswa. Perbandingan data-data hasil belajar siswa berdasarkan temuan penelitian, secara ringkas dirangkum pada Tabel 2.

Tabel 2. Perbandingan Data Hasil Belajar IPS Siswa Berdasarkan Strategi Pembelajaran dan Kecerdasan Ganda Siswa

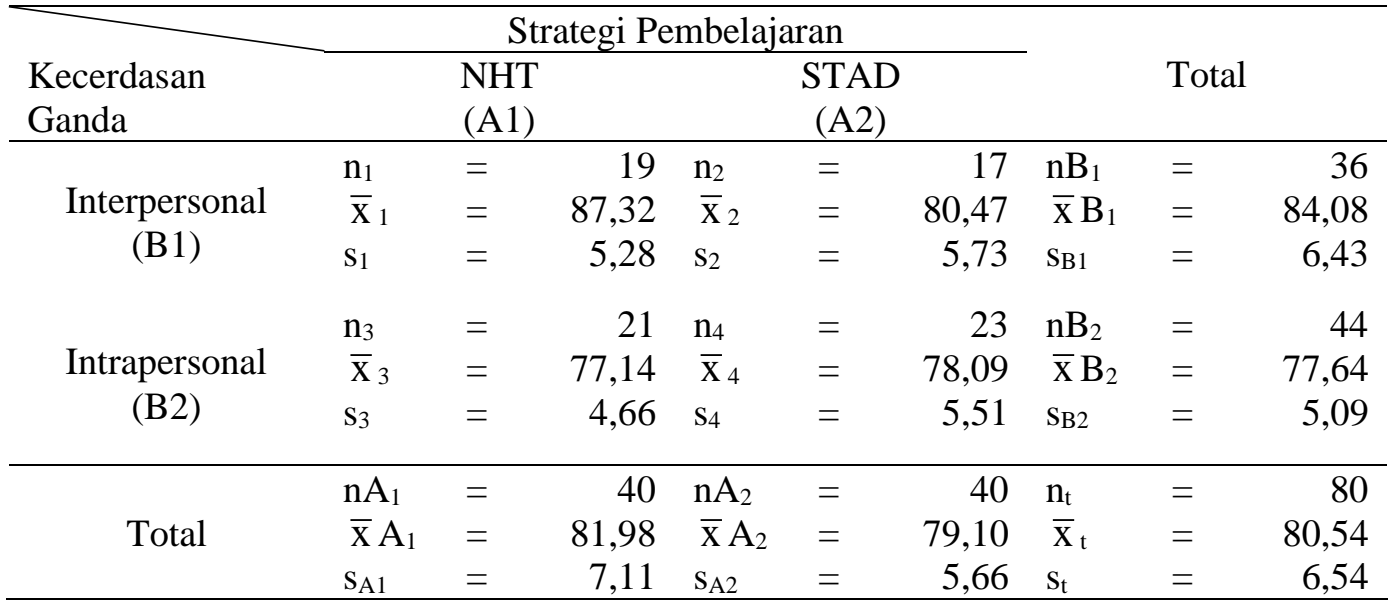

\section{Pengujian Hipotesis}

Pengujian hipotesis dilakukan menggunakan teknik analisis varians (anava) dua jalur dengan desain faktorial $2 \times 2$. Hasil perhitungan analisis varians dua jalur, secara ringkas dirangkum pada Tabel 3.

Tabel 3. Rangkuman Hasil Pengujian Analisis Varians Dua Jalur

\begin{tabular}{lccrrc}
\hline \multicolumn{1}{c}{ Sumber Variasi } & $\mathrm{dk}$ & $\mathrm{JK}$ & $\mathrm{RK}=\mathrm{JK} / \mathrm{dk}$ & \multicolumn{1}{c}{$\mathrm{Fh}$} & $\mathrm{Ft}_{\alpha=0,05}$ \\
\hline Antar Kolom (A) & 1 & 165,313 & 165,313 & 5,896 & 3,98 \\
Antar Baris (B) & 1 & 822,956 & 822,956 & 29,354 & 3,98 \\
Interaksi (AB) & 1 & 264,881 & 264,881 & 9,448 & 3,98 \\
\hline Galat (Dalam) & 76 & 2130,738 & 28,036 & & \\
\hline
\end{tabular}


Perbedaan Hasil Belajar Siswa yang Dibelajarkan dengan Strategi Pembelajaran NHT dengan Strategi Pembelajaran STAD adalah:

Adapun hipotesis statistik, yang diuji

$\mathrm{H}_{\mathrm{o}}: \mu \mathrm{A}_{1} \leq \mu \mathrm{A}_{2}$

$\mathrm{H}_{\mathrm{a}}: \mu \mathrm{A}_{1}>\mu \mathrm{A}_{2}$

Hasil penelitian diperoleh rata-rata hasil

belajar IPS siswa yang diajarkan dengan strategi pembelajaran NHT sebesar 81,98 dan hasil belajar IPS untuk kelompok siswa yang diajarkan dengan strategi pembelajaran STAD diperoleh rata-rata sebesar 79,10. Berdasarkan hasil pada Tabel 11, diperoleh $F_{\text {hitung }}>F_{\text {tabel }}$ yaitu 5,896 >3,98 maka terima $\mathrm{H}_{\mathrm{a}}$ sehingga disimpulkan hasil belajar IPS siswa yang diajar dengan strategi pembelajaran NHT lebih tinggi dibandingkan hasil belajar siswa yang diajar dengan strategi pembelajaran STAD.

Perbedaan Hasil Belajar Siswa yang Memiliki Kecerdasan Interpersonal dengan Kecerdasan Intrapersonal adalah:

Adapun hipotesis statistik, yang diuji

$\mathrm{H}_{\mathrm{o}}: \mu \mathrm{B}_{1} \leq \mu \mathrm{B}_{2}$

$\mathrm{H}_{\mathrm{a}}: \mu \mathrm{B}_{1}>\mu \mathrm{B}_{2}$

Hasil temuan penelitian diperoleh ratarata hasil belajar IPS untuk kelompok siswa yang memiliki kecerdasan interpersonal sebesar 84,08 dan untuk kelompok siswa yang memiliki kecerdasan intrapersonal diperoleh rata-rata hasil belajar sebesar 77,64. Berdasarkan hasil pada Tabel 11, diperoleh $\mathrm{F}_{\text {hitung }}>\mathrm{F}_{\text {tabel }}$ yaitu 29,354> 3,98 maka terima $\mathrm{H}_{\mathrm{a}}$ sehingga disimpulkan bahwa hasil belajar IPS siswa yang memiliki kecerdasan interpersonal lebih tinggi dibandingkan hasil belajar IPS siswa yang memiliki kecerdasan intrapersonal.

\section{Interaksi Antara Strategi Pembelajaran dan Kecerdasan Ganda Siswa Terhadap Hasil Belajar IPS} adalah:

Adapun hipotesis statistik, yang diuji

$\mathrm{H}_{\mathrm{o}}: \mu \mathrm{A}><\mu \mathrm{B}=0$

$\mathrm{H}_{\mathrm{a}}: \mu \mathrm{A}>\langle\mu \mathrm{B} \neq 0$

Hasil temuan penelitian diperoleh ratarata hasil belajar IPS kelompok siswa yang diajarkan strategi pembelajaran NHT memiliki kecerdasan interpersonal sebesar 87,32; kelompok siswa yang diajarkan dengan strategi pembelajaran NHT memiliki kecerdasan intrapersonal sebesar 77,14; kelompok siswa yang diajarkan dengan strategi pembelajaran STAD memiliki kecerdasan interpersonal sebesar 80,47; dan kelompok siswa yang diajarkan dengan strategi pembelajaran STAD memiliki kecerdasan intrapersonal sebesar 78,09 . Selanjutnya hasil analisis varians pada Tabel 11, diperoleh $F_{\text {hitung }}>F_{\text {tabel }}$ yaitu 9,448 > 3,98 sehingga terima $\mathrm{H}_{\mathrm{a}}$ atau tolak $\mathrm{H}_{0}$ dan disimpulkan terdapat interaksi antara strategi pembelajaran dan kecerdasan ganda siswa tehadap hasil belajar IPS siswa.

Hasil pengujian yang ketiga menyatakan terdapat interaksi antara strategi pembelajaran dan kecerdasan ganda siswa terhadap hasil belajar IPS siswa. Karenanya, perlu dilakukan pengujian lanjutan untuk mengetahui rata-rata nilai kelompok mana yang memberi pengaruh lebih baik terhadap hasil belajar IPS siswa. Uji lanjut dilakukan dengan uji Scheffe.

Tabel 4. Rangkuman Hasil Uji Scheffe

\begin{tabular}{cccc}
\hline No. & $\begin{array}{c}\text { Perbandingan Rata-rata } \\
\text { Nilai Kelompok }\end{array}$ & $\mathbf{F}_{\text {hitung }}$ & $\begin{array}{c}\mathbf{F}_{\text {tabel }} \\
\mathbf{F}_{\mathbf{0}, \mathbf{0 5} ; \mathbf{3} ; \mathbf{7 6}}\end{array}$ \\
\hline 1 & $\mathrm{~A}_{1} \mathrm{~B}_{1}$ dengan $\mathrm{A}_{1} \mathrm{~B}_{2}$ & 36,872 & 8,16 \\
2 & $\mathrm{~A}_{1} \mathrm{~B}_{1}$ dengan $\mathrm{A}_{2} \mathrm{~B}_{1}$ & 15,016 & 8,16 \\
3 & $\mathrm{~A}_{1} \mathrm{~B}_{1}$ dengan $\mathrm{A}_{2} \mathrm{~B}_{2}$ & 31,617 & 8,16 \\
4 & $\mathrm{~A}_{1} \mathrm{~B}_{2}$ dengan $\mathrm{A}_{2} \mathrm{~B}_{1}$ & 3,716 & 8,16 \\
5 & $\mathrm{~A}_{1} \mathrm{~B}_{2}$ dengan $\mathrm{A}_{2} \mathrm{~B}_{2}$ & 0,353 & 8,16 \\
6 & $\mathrm{~A}_{2} \mathrm{~B}_{1}$ dengan $\mathrm{A}_{2} \mathrm{~B}_{2}$ & 1,975 & 8,16 \\
\hline
\end{tabular}

Berdasarkan Tabel 4, diperoleh:

a. $\quad F_{\text {hitung }}>F_{\text {tabel }}$ yaitu 36,872 $>8,16$ sehingga disimpulkan ada perbedaan yang signifikan antara hasil belajar siswa yang dibelajarkan strategi pembelajaran NHT memiliki kecerdasan interpersonal (A1B1) dibandingkan siswa yang dibelajarkan strategi pembelajaran NHT memiliki kecerdasan intrapersonal (A1B2). Kelompok A1B1 (87,32) memperoleh 
hasil belajar lebih tinggi dibandingkan A1B2 $(77,14)$.

b. $\quad F_{\text {hitung }}>F_{\text {tabel }}$ yaitu $15,016>8,16$ sehingga disimpulkan ada perbedaan yang signifikan antara hasil belajar siswa yang dibelajarkan strategi pembelajaran NHT memiliki kecerdasan interpersonal (A1B1) dibandingkan siswa yang dibelajarkan strategi pembelajaran STAD memiliki kecerdasan interpersonal (A2B1). Kelompok A1B1 (87,32) memperoleh hasil belajar lebih tinggi dibandingkan A2B1 $(80,47)$.

c. $\quad F_{\text {hitung }}>F_{\text {tabel }}$ yaitu 31,617 $>8,16$ sehingga disimpulkan ada perbedaan yang signifikan antara hasil belajar siswa yang dibelajarkan strategi pembelajaran NHT memiliki kecerdasan interpersonal (A1B1) dibandingkan siswa yang dibelajarkan strategi pembelajaran STAD memiliki kecerdasan intrapersonal (A2B2). Kelompok A1B1 (87,32) memperoleh hasil belajar lebih tinggi dibandingkan A2B2 $(78,09)$.

d. $\quad F_{\text {hitung }}<F_{\text {tabel }}$ yaitu 3,716 $<8,16$ sehingga disimpulkan tidak ada perbedaan yang signifikan antara hasil belajar siswa yang dibelajarkan strategi pembelajaran NHT memiliki kecerdasan intrapersonal (A1B2) dibandingkan siswa yang dibelajarkan strategi pembelajaran STAD memiliki kecerdasan interpersonal (A2B1). Hasil belajar kelompok A1B2 $(77,14)$ tidak lebih tinggi dibandingkan kelompok A2B1 $(80,47)$ atau selisih rata-rata 3,33 .

e. $\quad F_{\text {hitung }}<F_{\text {tabel }}$ yaitu $0,353<8,16$ sehingga disimpulkan tidak ada perbedaan yang signifikan antara hasil belajar siswa yang dibelajarkan strategi pembelajaran NHT memiliki kecerdasan intrapersonal (A1B2) dibandingkan siswa yang dibelajarkan strategi pembelajaran STAD memiliki kecerdasan intrapersonal (A2B2). Hasil belajar kelompok A1B2 $(77,14)$ tidak lebih tinggi dibandingkan kelompok A2B2 $(78,09)$ atau selisih rata-rata 0,95 .

f. $\quad F_{\text {hitung }}<F_{\text {tabel }}$ yaitu $1,975<8,16$ sehingga disimpulkan tidak ada perbedaan yang signifikan antara hasil belajar siswa yang dibelajarkan strategi pembelajaran STAD memiliki kecerdasan interpersonal (A2B1) dibandingkan siswa yang dibelajarkan strategi pembelajaran STAD memiliki kecerdasan intrapersonal (A2B2). Hasil belajar kelompok A2B1 $(80,47)$ tidak lebih tinggi dibandingkan kelompok A2B2 $(78,09)$ atau selisih rata-rata 2,38.

Sesuai dengan kerangka berpikir, maka menunjukkan ada interaksi antara strategi pembelajaaran dan kecerdasan ganda terhadap hasil belajar siswa yaitu untuk kelompok siswa yang memiliki kecerdasan interpersonal diajarkan dengan strategi pembelajaran NHT lebih tinggi dari kelompok siswa yang memiliki kecerdasan interpersonal diajarkan dengan strategi pembelajaran STAD secara signifikan $(87,32>80,47)$ pada butir (b) uji Scheffe, dan untuk kelompok siswa yang memiliki kecerdasan intrapersonal diajarkan dengan strategi pembelajaran STAD hasil belajarnya secara signifikan tidak lebih tinggi daripada kelompok siswa yang memiliki kecerdasan intrapersonal diajarkan dengan strategi pembelajaran NHT $(78,09 \approx 77,14)$ pada butir (e) uji Scheffe.

Adanya interaksi antara strategi pembelajaran dan kecerdasan ganda siswa terhadap hasil belajar IPS siswa, dapat divisualisasikan pada Gambar 1.

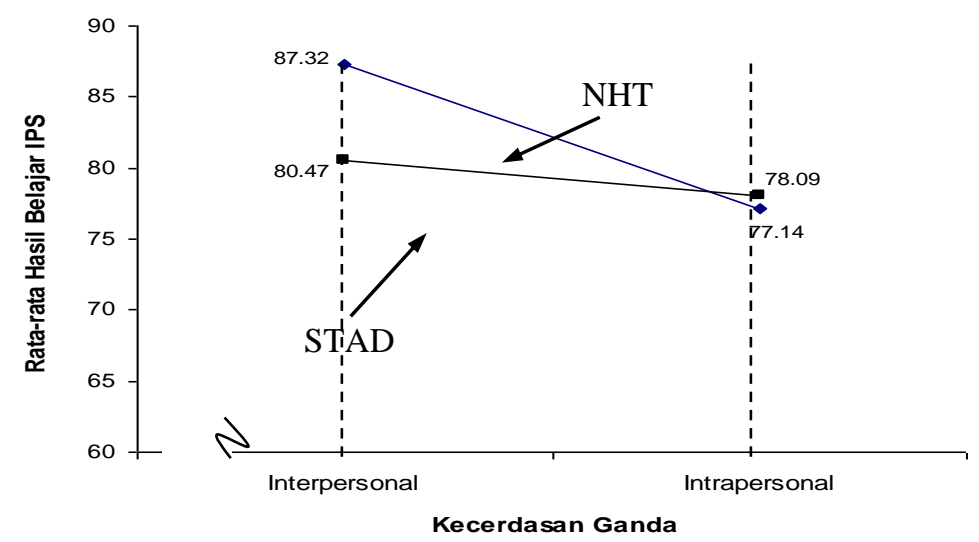

Gambar 1. Pola Interaksi Antara Strategi Pembelajaran dan Kecerdasan Ganda Terhadap Hasil Belajar IPS Siswa 


\section{PEMBAHASAN}

Penelitian yang dilakukan Akbar (2010) yang menyimpulkan bahwa penerapan model pembelajaran tipe STAD dapat meningkatkan hasil belajar mata pelajaran komunikasi pada pokok bahasan melakukan komunikasi tertulis. Penelitian Yuliati, $d k k$ (2012), menyimpulkan bahwa ada perbedaan hasil belajar siswa dalam pembelajaran Akuntansi antara siswa yang pembelajarannya menggunakan model NHT dan STAD, hasil belajar siswa yang diajar dengan NHT secara keseluruhan menunjukkan lebih tinggi dibandingkan dengan siswa yang diajar dengan STAD. Selanjutnya penelitian Khoiriyah, $d k k$ (2011), menyimpulkan bahwa terdapat perbedaan hasil belajar kimia antara siswa yang diberi metode NHT dengan metode STAD dan metode NHT dapat memberikan hasil belajar kimia yang lebih tinggi daripada metode STAD.

Hasil tabulasi dan temuan penelitian diperoleh rata-rata hasil belajar IPS siswa yang memiliki kecerdasan interpersonal (baik yang diajar dengan strategi pembelajaran NHT maupun STAD) sebesar 84,08. Sedangkan ratarata hasil belajar IPS siswa yang memiliki kecerdasan intrapersonal (baik yang diajar dengan strategi pembelajaran NHT maupun STAD) sebesar 77,64. Hasil pengujain hipotesis diperoleh nilai $F_{\text {hitung }}>F_{\text {tabel }}$ yaitu 29,354 $>3,98$ sehingga hipotesis kedua yang diajukan diterima dan disimpulkan bahwa hasil belajar IPS siswa yang memiliki kecerdasan interpersonal lebih tinggi dibandingkan kelompok siswa yang memiliki kecerdasan intrapersonal. Berdasarkan rata-rata nilai siswa menunjukkan bahwa rata-rata hasil belajar IPS kelompok siswa yang memiliki kecerdasan interpersonal sebesar 8,3\% lebih tinggi dibandingkan kelompok siswa yang memiliki kecerdasan intrapersonal.

Didukung oleh penelitian Munawaroh dan Lisfuroe'ah (2009), yang menyimpulkan bahwa terdapat perbedaan yang signifikan hasil belajar matematika antara kelompok siswa yang berkecerdasan interpersonal jika dibandingkan dengan kelompok siswa yang berkecerdasan intrapersonal.

Hasil pengelompokkan data diperoleh rata-rata hasil belajar IPS untuk kelompok siswa yang memiliki kecerdasan interpersonal dengan strategi pembelajaran NHT sebesar 87,32 ; kelompok siswa yang memiliki kecerdasan intrapersonal diajarkan strategi pembelajaran NHT diperoleh rata-rata hasil belajar sebesar 77,14; kelompok siswa yang memiliki kecerdasan interpersonal diajarkan strategi pembelajaran STAD diperoleh rata-rata hasil belajar sebesar 80,47; sedangkan kelompok siswa yang memiliki kecerdasan intrapersonal diajarkan strategi pembelajaran STAD diperoleh rata-rata hasil belajar sebesar 78,09 .

Mendukung penelitian Bukit (2008) yang menyimpulkan bahwa terdapat pengaruh yang signifikan antara strategi pembelajaran peta konsep diawal dan diakhir dengan kecerdasan ganda (intrapersonal dan interpersonal) terhadap hasil belajar Biologi, serta terdapat interaksi antara strategi pembelajaran peta konsep dan komunikasi ganda terhadap hasil belajar Biologi.

Berdasarkan rata-rata hasil belajar yang diperoleh siswa memberi indikasi bahwa kelompok siswa yang memiliki kecerdasan interpersonal akan memperoleh hasil belajar yang lebih baik jika diajarkan dengan strategi pembelajaran NHT dibandingkan strategi pembelajaran STAD. Dengan demikian, dari hasil temuan penelitian dan pengujian hipotesis terbukti bahwa ada pengaruh strategi pembelajaran dan kecerdasan ganda siswa terhadap hasil belajar IPS siswa baik secara terpisah maupun interaksi atau bersamaan.

\section{SIMPULAN}

1. Hasil belajar IPS siswa yang diajar dengan menggunakan strategi pembelajaran NHT lebih tinggi dibandingkan hasil belajar siswa yang diajarkan dengan strategi pembelajaran STAD. Dengan demikian, dalam mengajarkan konsep-konsep IPS diharapkan guru dapat menggunakan strategi pembelajaran NHT agar belajar siswa jadi lebih menyenangkan dan bermakna sehingga siswa dapat memperoleh hasil belajar yang lebih baik.

2. Hasil belajar IPS siswa yang memiliki kecerdasan interpersonal lebih tinggi dibandingkan siswa yang memiliki kecerdasan intrapersonal. Oleh karena itu, dalam mengajarkan IPS hendaknya guru berusaha menumbuh kembangkan kecerdasan ganda siswa terutama kecerdasan interpersonal.

3. Terdapat interaksi antara strategi pembelajaran dan kecerdasan ganda tehadap hasil belajar IPS siswa. Hal ini memberi makna bahwa interaksi antara strategi pembelajaran dan kecerdasan 
ganda siswa mempengaruhi hasil belajar IPS siswa. Berdasarkan nilai rata-rata siswa memberi indikasi bahwa kelompok siswa yang memiliki kecerdasan interpersonal lebih tepat diajarkan strategi pembelajaran NHT sedangkan siswa yang memiliki kecerdasan intrapersonal lebih tepat diajarkan strategi pembelajaran STAD.

\section{DAFTAR PUSTAKA}

Amstrong, Thomas. 2003. In Their Own Way: Discovering and Encouraging Your Child's Multiple Intelligences. (alih bahasa). Jakarta: Gramedia Pustaka Utama.

Amstrong, Thomas. 2004. Menerapkan Multiple Intelligences di Sekolah, (alih bahasa Yudhi Murtanto), Bandung: Kaifa.

Arikunto, Suharsimi. 2003. Dasar-dasar Evaluasi Pendidikan. Yogyakarta: Bumi Aksara.

Budiningsih, Asri. 2008. Belajar dan Pembelajaran. Jakarta: Rineka Cipta.

Bukit, Julia Damaris. 2008. Pengaruh Strategi Pembelajaran Peta Konsep Dan Kecerdasan Ganda Siswa Terhadap Hasil Belajar Biologi. Tesis Tidak Diterbitkan), Medan: PPs UNIMED.

Chaplin. 1972, Dictionary Of Psychology, Fifth Printing, New York: Dell Publishing co. Inc.

Davies, Ivor K. 1991. Pengelolaan Belajar. Jakarta: Rajawali.

Dick \& Carey, 2005, The Systematic Design Of Instruction, Boston: Allyn And Bacon.

Dimyati dan Mudjiono. 2006. Belajar dan Pembelajaran. Jakarta: Rineka Cipta.

Djamrah, Sayiful Bahri dan Aswan Zain. 2010. Strategi Belajar Mengajar. Jakarta: Rineka Cipta.

Elliott, Stephen, N. dkk. 2000. Educational Psychology Effective Learning third editor, New York: McGraw Hill.

Gardner, Howard. 1983. Frames Of Mind: The Theory of Multiple Intelligences, tenthanniversary edition, New York: Basic Books.

Gardner, Howard. 1993. Multiple Intelligences: The Theory in Practice. New York: Basic Books.

Gardner, Howard. 2000. Intellegence Reframed: Multiple Intelligences for the $21^{s t}$ Century. New York: Basic Books.
Gunawan, Adi. 2003. Genius Learning Strategy, Jakarta: Gramedia Pustaka Utara.

Hamid, K. Abdul. 2009. Teori Belajar dan Pembelajaran. Medan.

Hasan, S. Hamid. 1996. Pendidikan Ilmu-ilmu Sosial (Buku I). Bandung: Jurusan Sejarah FIPS IKIP Bandung.

Ibrahim, Muslimin, dkk. 2000. Pembelajaran Kooperatif. Universitas Negeri Surabaya: University Press.

Isjoni. 2009. Pembelajaran Kooperatif. Yogyakarta: Pustaka Pelajar.

Joni, T.R. 1985. Strategi Belajar Mengajar Suatu Tinjauan Pengantar. Penerbit P2LPTK Dirjen Pendidikan Tinggi Depdikbud.

Khoiriyah, Lilis Husniyatin., A.Tri Widodo, Wisnu Sunarto. 2011. Komparasi Hasil Belajar Kimia Menggunakan Model Pembelajaran Kooperatif NHT dengan STAD di SMA Negeri I Kedungwuni, http://lib.unnes.ac.id/9189/ 1/11498a.pdf. diakses tanggal 19 Juli 2012 Jam 9:00 WIB.

Lazear, David. 2000. Pathways of Learning Teaching Students and Parents About Multiple Intelligences, Arizona, Tucson: Zephyr Press.

Lie, Anita. 2002. Cooperative Learning. Jakarta: Grasindo.

Miarso, Yusuf Hadi. 2007. Menyemai Benih Teknologi Pendidikan. Jakarta: Kencana Prenada Media Group.

Miarso, Yusuf Hadi. 2009. Menyemai Benih Teknologi Pendidikan. Jakarta: Kencana Prenada Media Group.

Munawaroh, Mumun dan E'ah Lisfuroe'ah. 2009. Perbandingan Hasil Belajar Siswa antara yang Berkecerdasan Interpersonal dengan yang Berkecerdasan Intrapersonal dalam Mata Pelajaran Matematika. EduMa, Vol. 1, No. 2, Desember 2009:143-150.

Musfiroh, Tadkiroatun. 2008. MULTIPLE INTELLIGENCES dan Implikasinya dalam Pendidikan, http://staff.uny.ac.id/sites/default/files/tm p/MULTIPLE INTELLIGENCES. diakses tanggal 9 Februari 2012 Jam 9:00 WIB.

Nasution, S. 2009. Kurikulum dan Pengajaran, Bandung: Bumi Aksara. 
Nur, Muhammad. 2005. Pembelajaran Kooperatif. Surabaya: Pusat Sains dan Matematika Sekolah UNESA.

Rahmawati, Noviani Dini. 2011. Eksperimentasi Model Pembelajaran Kooperatif Tipe Teams Games Tournament (TGT) dan Numbered Heads Together (NHT) Pada Materi Pokok Sistem Persamaan Linear Dua Variabel Ditinjau Dari Aktivitas Belajar Siswa SMP Negeri Se-Kabupaten Grobogan. Prosiding Seminar Nasional Matematika Prodi Pendidikan Matematika, Universitas Muhammadiyah Surakarta, 24 Juli 2011.

Safaria, T. 2005. Interpersonal Intelligence: Metode Pengembangan Kecerdasan Interpersonal Anak. Yogyakarta: Amara Books.

Sampels, Bob. 2002. Revolusi Belajar Untuk Anak Panduan Belajar Sambil Bermain Untuk Membuka Pikiran Anak-Anak Anda (alih bahasa Rahmani Astuti) Bandung: Kaifa.

Sanjaya, Wina. 2010. Strategi Pembelajaran Berorientasi Standar Proses Pendidikan. Jakarta: Prenada Media Group.

Semiawan, Conny, R. 2004. Perkembangan Anak Usia Dini, Makalah disampaikan pada Seminar dan Lokakarya Nasional Pendidikan Anak Usia Dini, Kerjasama Dirjen PLSP Depdiknas dengan UNJ, Jakarta, 9 - 11 Oktober 2004.

Slameto, 2010. Belajar dan Faktor-faktor Yang Mempengaruhinya. Jakarta: Rineka Cipta.

Slavin, Robert dan Masri Kuadrat E. 2008. Cooperative Learning: Theory, Research and Praktice.

Solihatin, Etin dan Raharjo. 2009. Cooperative Learning Jakarta: Bumi Aksara.

Suarca, Kadek., Soetjiningsih, dan IGA. Endah Ardjana. 2005. Kecerdasan Majemuk Pada Anak. Sari Pediatri, Vol. 7, No. 2, September 2005: 85-92.
Sugiyono. 2008. Metode Penelitian Pendidikan. Bandung: Alfabet.

Sujiono, Yuliani Nurani dan Bambang Sujiono. 2010. Bermain Kreatif Berbasis Kecerdasan Jamak. Jakarta: Indeks.

Suwarna, Al Muchtar. 2009. Strategi Pembelajaran Pendidikan IPS, Bandung: Sekolah Pascasarjana Universitas Pendidikan Indonesia.

Syah, Muhibbin. 2011. Psikologi Belajar. Jakarta: Grafindo.

Trianto. 2011. Mendesain Model Pembelajaran Inovatif-Progresif. Jakarta: Kencana Prenada Media Group.

Tukimun. 2006. Pengaruh Pembelajaran Konstruktivisme Melalui Penerapan Pembelajaran Kelompok Balik dan Kemampuan Berpikir Matematis Terhadap Hasil Belajar Fisika Siswa Kelas X SMA Negeri I Binjai. Tesis Tidak Diterbitkan. Medan: PPs UNIMED.

Uno, Hamzah B, dan Masri Kuadrat. 2010. Mengelola Kecerdasan Dalam Pembelajaran. Jakarta: Bumi Aksara.

Wijanarko, Jarot. 2010. Multiple Intelligences. Serpong: The Happy Holy Kids.

Winarto, Paulus. 2010. Maximizing Your Talent: Menemukan dan Memaksimalkan Potensi Diri Anda. http://blog.pauluswinarto.com/ ttalentaweb.pdf - Tes Kecerdasan Majemuk.pdf. diakses tanggal 19 Juli 2012 Jam 9:00 WIB.

Yuliati, Maulina., R. Gunawan, dan Eddy Purnomo. 2012. Perbedaan Hasil Belajar Akuntansi Model Pembelajaran Number Head Together (NHT) dan Tipe Student Teams Achievement Division (STAD) Pada Siswa Kelas X SMK YP Serdang Tanjung Bintang Lampung Selatan Tahun 2011-2012. Tesis Tidak Diterbitkan. Pascasarjana Program Pendidikan IPS FKIP Universitas Lampung. 